\title{
Politie en burgers: van informatie delen naar volwaardige samenwerking ${ }^{*}$
}

\author{
José Kerstholt, Arnout de Vries, Maj Roy Mente \& Mirjam Huis in 't Veld
}

\begin{abstract}
De politieorganisatie maakt steeds meer gebruik van de capaciteit, kennis en kunde van burgers, vooral in de context van het Gebiedsgebonden Politiewerk (GGPW). Dit artikel geeft een overzicht van de huidige stand van zaken. Voor de verschillende vormen van participatie hebben we een indeling gemaakt naar de mate van invloed en specifiek veiligheidsdomein. We concluderen dat sociale media een steeds belangrijker rol spelen in de interactie tussen politie en burgers, wat nieuwe mogelijkheden creëert voor verdergaande samenwerking.
\end{abstract}

\section{$1 \quad$ Inleiding}

In zowel de VS als Europa is er toenemende aandacht voor Gebiedsgebonden Politiewerk (GGPW, Community Oriented Policing in de Engelstalige literatuur). In tegenstelling tot het traditionele politiewerk waarbij het accent op rechts- en ordehandhaving ligt, is binnen het GGPW-concept het betrekken van burgers in de preventiefase van groter belang. Uit verschillende overzichtsartikelen komt naar voren dat GGPW positieve effecten heeft op uitkomsten als de tevredenheid van burgers, de perceptie van overlast en verloedering en de legitimiteit van de politie, maar slechts beperkte effecten heeft op de reductie van criminaliteit (Gill, Weisburg, Telep, Vitter \& Bennett 2014; Land, Stokkom \& Boutellier 2014; Weisburd \& Eck 2004).

Hoewel de directe effecten van GGPW op criminaliteitsreductie beperkt lijken, zijn er wel indirecte effecten. Een toename van gepercipieerde legitimiteit leidt er bijvoorbeeld toe dat burgers eerder meewerken met de politie en dat de criminaliteit afneemt (Bradford, Jackson \& Hough 2013; Mazerolle, Antrobus, Bennett \& Tyler 2013). Daarnaast werd in een recente meta-analyse van Braga, Welsh en Schnell (2015) ook aangetoond dat reductie van overlast en verloedering tot minder criminaliteit leidt. Al met al zijn er dus aanwijzingen dat de kortetermijneffecten van GGPW vooral tot uiting komen in psychosociale factoren als beleving en vertrouwen, maar dat deze effecten op de lange termijn wel degelijk een effect hebben op het voorkomen van criminaliteit.

Omdat veel conclusies zijn gebaseerd op onderzoek in Amerikaanse buurten, geven we in onderhavig artikel een overzicht van GGPW in Nederland, waarbij we ook aandacht besteden aan de rol van sociale media. We streven daarbij niet naar een complete weergave van alle evaluaties en effecten, maar het doel is vooral om de huidige stand van zaken te schetsen als basis voor het definiëren van vervolg-

* Dit onderzoek werd uitgevoerd in het kader van het Europese project INSPEC ${ }^{2} \mathrm{~T}$ (Inspiring CitizeNS Participation for Enhanced Community PoliCing AcTions); http://inspec2t-project.eu. 
stappen die nodig zijn om de samenwerking met burgers (nog meer) te verbeteren naar een volgende generatie van GGPW.

Algemeen worden voor GGPW drie kernfactoren onderscheiden: samenwerking met burgers, decentrale aansturing en het oplossen van problemen. GGPW gaat dus niet over het simpelweg verbeteren van de relatie tussen de politie en burgers, maar het richt zich specifiek op het oplossen van een probleem waarbij ook de capaciteit en expertise van burgers (en mogelijk private partijen) worden ingezet. De centrale vraagstelling van deze studie is derhalve welke effecten er zijn gevonden van GGPW op zowel organisatieniveau als de directe samenwerking met burgers.

\section{Gebiedsgebonden politiewerk}

De belangrijkste redenen voor een landelijke implementatie van GGPW in Nederland in de jaren negentig van de vorige eeuw waren dat de politie: 1 ) meer direct zicht wilde hebben op relevante problemen in de wijk; 2) kon mediëren tussen relevante belanghebbenden; en 3) meer autoriteit kon opbouwen (Boin, Van der Torre, 't Hart \& Van der Meulen 2003; Vijver \& Zoomer 2004). De politie moest uit zijn isolement komen en het vertrouwen van burgers moest toenemen. Dus naast het bevorderen van veiligheid was het doel om via een lokale inbedding van de politie meer legitimiteit en vertrouwen van het publiek op te bouwen.

Binnen een basisteam zijn de wijkagenten sleutelfiguren voor de centrale doelen van GGPW, omdat zij in direct contact staan met de lokale gemeenschap. In principe is er één wijkagent per 5000 burgers; zij voeren voor $80 \%$ van hun tijd activiteiten uit ten behoeve van de lokale gemeenschap. De wijkagenten werken daarbij samen met het basisteam, andere delen van de politieorganisatie, externe belanghebbenden en burgers.

Uit de Veiligheidsmonitor van 2014 (CBS 2014) blijkt dat een kwart van de bewoners (zeer) tevreden is met het functioneren van de politie in de buurt, wat ongeveer overeenkomt met de cijfers uit 2012 en 2013. Opvallend is dat het grootste deel (42\%) aangeeft dit niet te kunnen beoordelen. Ongeveer $40 \%$ van de respondenten vond dat de politie burgers serieus neemt, bescherming biedt, reageert op problemen in de buurt en haar best doet. Slechts $20 \%$ vindt dat de politie contact heeft met bewoners in de buurt en zaken efficiënt aanpakt. Mensen zijn het meest negatief (49\%) over de zichtbaarheid van de politie. Deze resultaten tonen aan dat er nog wel degelijk ruimte is voor verbetering van de relatie tussen burgers en politie.

\section{Methode}

We hebben voor dit onderzoek gekozen voor een pragmatische aanpak, met als uitgangspunt een aantal recente kernpublicaties: voor organisatieaspecten Gooren, Os en Rookhuijzen (2013), Terpstra (2011) en Vijver en Zoomer (2004) en voor burgerparticipatie een recent overzichtsrapport van Van der Land e.a. (2014). Uitgaande van deze artikelen hebben we verder gezocht naar gerelateerde 
artikelen. Omdat sociale media een steeds belangrijker instrument zijn geworden binnen het GGPW, hebben we speciaal aandacht besteed aan de effecten van het gebruik van sociale media. Als uitgangpunt hiervoor gebruikten we Vries en Smilda (2013).

De resultaten zijn ingedeeld naar organisatieaspecten en burgerparticipatie. Voor de effecten van burgerparticipatie hebben de verschillende initiatieven, uitgaande van de indeling van Van der Land e.a. (2014), ingedeeld langs twee dimensies: domein (bijvoorbeeld preventie en handhaving) en mate van (burger)invloed (bijv. informeren of adviseren).

\section{Resultaten}

Een algemene bevinding is dat op zowel organisatieniveau als in de interactie met burgers vertrouwen een centrale rol speelt. Om vertrouwen te kunnen winnen is het noodzakelijk dat de politie zichtbaar en herkenbaar is op wijkniveau. Uit onderzoek blijkt inderdaad dat het vertrouwen kan toenemen als men de wijkagent kent (Beunders, Abraham, Van Dijk \& Van Hoek 2011). Naast zichtbaarheid en herkenbaarheid zijn ook eerlijkheid en rechtvaardigheid van belang (Flight, Van Andel \& Hulshof 2006). Aangetoond werd dat de perceptie van eerlijkheid en rechtvaardigheid belangrijker is voor de legitimiteit dan de gepercipieerde effectiviteit (Hough, Jackson, Bradford, Myhill \& Quinton 2010). Met andere woorden: de manier waarop de politie omgaat met burgers is belangrijker dan de objectieve resultaten.

\subsection{Organisatie}

Net als in internationale studies heeft de Nederlandse wijkagent de taak om voor veiligheid in de wijk te zorgen, daarbij samen te werken met andere partijen en burgers te activeren om met hem of haar samen te werken (Vijver \& Zoomer 2004). Effecten van GGPW blijken echter lastig te meten door onder meer de ambiguïteit van het concept en de specifieke doelen (Terpstra 2009; Van der Vijver \& Zoomer 2004). Bovendien moet het concept adequaat geïmplementeerd zijn (Van der Vijver \& Zoomer 2004). Als te vroeg wordt geëvalueerd, worden eerder implementatieproblemen gemeten dan de feitelijke effecten. Een laatste complicerende factor is dat GGPW per definitie een samenwerkingsverband is van meerdere partijen, waardoor effecten niet toegeschreven kunnen worden aan één afzonderlijke partij.

Hoewel de criminaliteit over de afgelopen jaren is gedaald (in 2014 werden zelfs $8 \%$ minder misdrijven geregistreerd dan in 2013), is het niet duidelijk waar dit precies aan moet worden toegeschreven. Het algemene effect van GGPW had vastgesteld kunnen worden bij de invoering, maar dat heeft alleen in Haarlem plaatsgevonden (Van der Vijver \& Zoomer 2004). De effecten waren daar echter wel positief: minder criminaliteitgerelateerde problemen, minder angst voor criminaliteit en burgers dachten positiever over de politie. Als antwoord op het ambigue karakter van GGPW analyseerde Terpstra (2011) de dagelijkse praktijk van wijkagenten en concludeerde dat er een discrepantie is tussen de theorie en 
de praktijk. Werkgebieden zijn vaak groot, er is slechts beperkte tijd om op straat door te brengen en er is in het algemeen weinig beleid over hoe GGPW toegepast zou moeten worden. Hierdoor is het contact met burgers doorgaans beperkt en in de praktijk zijn wijkagenten slechts geïnteresseerd in één specifieke vorm van burgerparticipatie: burgers als bron van informatie.

Gooren, Os en Rookhuijzen (2013) geven aan dat een decentraal sturingsconcept het best past bij GGPW, wat zich uit in: 1) autonomie van het gebiedsteam, 2) territoriale aansturing en 3 ) sturing op hoofdlijnen. Dit doel is nog niet geheel gerealiseerd, wat onder meer wordt veroorzaakt door doorgeschoten procesdenken. Hierdoor is het werk meer gericht op wat het systeem vraagt dan op wat voor de burger belangrijk is. Voor de lokale GGP moet er ruimte zijn voor de wijkagent om oplossingen te bedenken die bij de lokale context passen, waarbij het systeem faciliterend is.

\subsection{Rol van sociale media}

Door technologische innovaties verandert de interactie tussen burgers en organisaties, zowel privé als zakelijk. Steeds meer mensen, en ook de organisaties waar zij mee interacteren, gebruiken digitale communicatiemiddelen. Sociale media zijn ontwikkeld om de dialoog met een groot publiek te verbeteren ('many-tomany'-interactie) (Bertot, Jaeger \& Hansen 2012). Door sociale media kan op een snelle manier met een grote groep mensen worden geïnteracteerd en het toenemende gebruik ervan binnen de politie heeft waarschijnlijk een grote invloed op de relatie met burgers.

Het eerste politieaccount op Twitter werd geregistreerd op 24 juli 2009 en in maart 2012 waren er 1000 accounts, waarvan 755 van wijkagenten (Meijer, Grimmelikhuijsen, Fictorie, Thaens \& Siep 2012). Die 1000 politieaccounts hadden meer dan 770.000 volgers, dus een gemiddelde van 770 volgers per account. In maart 2011 was dit toegenomen naar 150.000 volgers. In de loop van 2015 waren er al meer dan 2000 politieaccounts met gezamenlijk meer dan vier miljoen volgers en zat de meerderheid van de wijkagenten op Twitter. Het aantal Twitteraccounts en -volgers is dus duidelijk snel aan het toenemen, wat Twitter en andere sociale-mediaplatformen, zoals Facebook, tot serieuze communicatiemiddelen maakt, zowel voor het uitwisselen van informatie als voor het opbouwen en onderhouden van een vertrouwensrelatie (Roodenburg \& Boutellier 2014).

Twitterende wijkagenten spenderen tussen 10 en 30 minuten per dag aan het zelf sturen van een tweet of het reageren op tweets van anderen (Meijer e.a. 2012). De inhoud van de tweets gaat over waar ze op dat moment mee bezig zijn, over wijkgerelateerde criminaliteit of aanhoudingen. Ongeveer $80 \%$ van de twitterende wijkagenten zegt te twitteren over tips met betrekking tot preventie, een kwart vraagt burgers mee te denken met specifieke vraagstukken en slechts een klein deel zegt over privézaken te twitteren. Vaak melden wijkagenten overigens wel dat ze met vakantie gaan, om daarmee aan te geven dat reacties wat langer op zich kunnen laten wachten of ze verwijzen naar een collega. De wijkagenten hoeven slechts vrij globale richtlijnen te volgen bij het opstellen van tweets, maar vaak wordt hun twittergedrag wel gevolgd vanuit de organisatie en in sommige korpsen heeft het management ook toegang tot de accounts van de wijkagenten. 
Ook op lokaal niveau volgen wijkagenten elkaar vaak, waardoor zij kennis kunnen delen en ook weet hebben van actuele zaken die in andere wijken spelen.

\subsection{Burgerparticipatie}

Binnen het concept van GGPW is er een breed scala aan mogelijkheden om burgers te betrekken bij politietaken en zo samen te werken aan het verhogen van de veiligheid in de buurt. Van der Land, Van Stokkom en Boutellier (2014) maakten in een recent overzicht een onderscheid in zeven vormen van burgerparticipatie in het politiedomein: 1) Toezicht: informele sociale controle in de (semi)openbare ruimte waarbij, mogelijk met behulp van technologie, ongewenste situaties gecommuniceerd kunnen worden (bijv. buurtwachten en Whatsappgroepen), 2) Opsporing: informatie verzamelen ten behoeve van de opsporing van verdachte personen en zo criminaliteit en overlast actief tegengaan (bijv. Opsporing Verzocht), 3) Zorg voor de openbare ruimte: verbeteren en verfraaien van de openbare ruimte (bijv. bewonersbudgetten, Opzoomer-achtige projecten), 4) Conflictbemiddeling: bewoners met vaardigheden uitrusten om zelf onderlinge conflicten op te lossen en zo de woonoverlast in buurten terug te dringen (bijv. buurtbemiddeling), 5) Contactbevordering: contact bevorderen tussen bewoners of tussen bewoners en de politie en zo het onderlinge vertrouwen vergroten (bijv. gedragscodes), 6) Informatiebemiddeling: informatie verzamelen en toegankelijk maken (bijv. Politie-app), 7) Beleidsbeïnvloeding: vergroten van de zeggenschap van burgers bij de totstandkoming van beleid gepaard aan coproductie in de uitvoering van beleid (bijv. Buurt Bestuurt en Veilige Buurten Teams).

De categorisatie die door Van der Land e.a. (2014) is voorgesteld, hebben we langs twee dimensies gestructureerd: betrokkenheid van burgers en veiligheidsdomein. Voor de betrokkenheid van burgers hebben we de participatieladder gebruikt zoals die in eerste instantie is beschreven door Arnstein (1969). Arnstein (1969) maakte een onderscheid in acht typen van burgerbetrokkenheid. De onderste sporten van de ladder zijn 'manipulatie' en 'therapie' en aangezien dit geen vormen van participatie zijn zoals hier bedoeld, hebben we deze twee vormen buiten beschouwing gelaten. De derde en vierde sport geven burgers een stem: informeren en consulteren. Informeren wordt meestal gedaan via instrumenten als nieuwsberichten, flyers of posters, terwijl het consulteren kan gebeuren via vragenlijsten of openbare bijeenkomsten. Op de vijfde sport (bedaren of tevredenstellen) beginnen burgers wat invloed te krijgen. Op dit niveau kan burgers om advies worden gevraagd, hoewel ze geen daadwerkelijke macht hebben, omdat ze geen beslissingen nemen. Op de laatste sporten (6: partnerschap, 7: gedelegeerde macht en 8: burgercontrole) hebben burgers daadwerkelijk invloed, omdat hier sprake is van een herverdeling van de macht via onderhandelingen tussen burgers en machthebbers. Voor ons doel hebben we een driedeling gemaakt voor de mate van burgerparticipatie: 1) informeren en consulteren, 2) adviseren en 3) coproduceren/meebeslissen. Daarnaast hebben we een onderscheid gemaakt in het veiligheidsdomein waarbinnen burgerparticipatie plaatsvindt: preventie, handhaving, opsporing en het hogere niveau 'kwaliteit van leven' (zie tabel 1). 
Tabel 1 Overzicht vormen van burgerparticipatie gerelateerd aan mate van invloed en domein

\begin{tabular}{lll}
\hline & $\begin{array}{l}\text { Informeren/ consul- Adviseren } \\
\text { teren }\end{array}$ & $\begin{array}{l}\text { Coproduceren/ } \\
\text { meebeslissen }\end{array}$ \\
\hline Preventie & $\begin{array}{l}\text { Informatiedeling Toe- } \\
\text { zicht (bijv. burger- } \\
\text { wacht) }\end{array}$ & \\
Handhaving & $\begin{array}{l}\text { Alertering (bijv. Bur- } \\
\text { gernet) } \\
\text { Burgeronderzoek (bijv. } \\
\text { meedenken met } \\
\text { lopende zaken) }\end{array}$ & $\begin{array}{l}\text { Beleidsbeïnloeding } \\
\text { (bijv. Buurt Bestuurt) }\end{array}$ \\
Kwaliteit van leven & & $\begin{array}{l}\text { Conflictmediatie Zorg } \\
\text { openbare ruimtes } \\
\text { (bijv. wijkbudgetten) }\end{array}$ \\
\hline
\end{tabular}

De rol van sociale media is voor alle vormen van burgerinitiatieven toegenomen. Daarbij is het van belang om op te merken dat online en offline participatie niet onafhankelijk van elkaar zijn. Online participatie moet gezien worden als een aanvulling op offline participatie in plaats van een vervanging. Een voorbeeld van deze toegevoegde waarde is het alerteringssysteem Burgernet, een instrument waarmee de politie burgers kan vragen om uit te kijken naar specifieke personen. Burgernet kan via Twitter worden gevolgd en de registratie gebeurt online, maar voor de alertering wordt gebruikgemaakt van de telefoon en SMS en is er sinds kort ook een app. Als burgers na een melding een gezochte persoon hebben gesignaleerd, kunnen ze dit aan de meldkamer doorgeven, waardoor de politie mogelijk het zoekgebied weer kan aanpassen. Er kan dus een mix van instrumenten worden gebruikt die optimaal is afgestemd op de specifieke situatie die zich voordoet.

\subsubsection{Informeren en consulteren}

De mogelijkheden om informatie met burgers te delen zijn enorm toegenomen met de komst van sociale media. Uit onderzoek van Veltman (2011) bleek bijvoorbeeld dat volgers op Twitter een positiever beeld hebben van de politieorganisatie. Deze positieve effecten werden echter niet alleen voor Twitter gevonden, maar eigenlijk in alle gevallen dat de politie gericht informatie deelde met burgers en hen betrok bij lokale politiezaken. Twitter bleek geen toegevoegde waarde te hebben in het vergroten van vertrouwen, maar er werd wel een klein effect gevonden op de gepercipieerde legitimiteit van de politie (Boverman, Van Duijn, De Graaf \& Ritzema 2011). Bovendien leidde het gebruik van Twitter tot een toename van gepercipieerde autoriteit, vooral voor wat betreft effectiviteit, zichtbaarheid en controleerbaarheid.

Een voorbeeld van een project in het preventiedomein zijn buurtpreventie- of interventieteams, waarbij burgers surveilleren in een publieke ruimte om vroegtijdig crimineel gedrag te detecteren of om crimineel gedrag te voorkomen (door bijvoorbeeld buurtbewoners te informeren dat er een raam openstaat). Het doel is om potentiële criminelen af te schrikken of aanstootgevend gedrag te beïnvloe- 
den. Deze buurtwachten kunnen ondersteund worden door bijvoorbeeld Whatsapp. Het effect van buurtwachten is tot op heden niet aangetoond, omdat de implementatie vaak een combinatie van interventies betrof (een uitzondering hierop vormt een recent onderzoek van de Universiteit van Tilburg, waarin werd aangetoond dat het aantal woninginbraken daalde als gevolg van Whatsapp-groepen (Akkermans \& Vollaard 2015)). Deelnemers waren echter wel positief over de inzet van buurtwachten, omdat ze meer veiligheid ervaren en hun gevoel van controle over de buurt is toegenomen. Dit geldt echter niet voor alle wijken. Voor sommige wijken nam het gevoel van onveiligheid zelfs toe, mogelijk in wijken waar het niveau van vertrouwen laag is (Eijck 2013).

Voor burgerparticipatie binnen het opsporingsdomein wordt ook steeds meer gebruikgemaakt van moderne technologieën als sociale media, apps en Facebook, waardoor zowel snelheid als efficiëntie van de informatie-uitwisseling is toegenomen (Meijer e.a. 2012). Via deze communicatiemiddelen wordt burgers meestal gevraagd of ze iets gezien of gehoord hebben, maar burgers zouden ook zienswijzen kunnen genereren over wat er mogelijk gebeurd zou kunnen zijn. Door hun grotere afstand van een zaak zouden burgers meer onconventionele of creatieve scenario's (opsporingshypothesen) kunnen verzinnen, wat vervolgens het opsporingsproces een nieuwe impuls kan geven. Zo staat er op de politiesite (www. politie.nl) een aantal dossiers met informatie over zaken (bijv. over de incidenten bij Jumbo-supermarkten in Groningen en Zwolle). Burgers wordt expliciet gevraagd tips te geven of mogelijke scenario's te genereren. Ook kunnen burgers aangeven of zij op de hoogte willen worden gehouden van het verloop van de zaak.

Binnen de handhaving is een scala aan instrumenten beschikbaar, die worden ingezet voor het signaleren van specifieke personen, waarvan Burgernet en Amber Alert waarschijnlijk de meest bekende zijn. Amber Alert wordt specifiek ingezet voor vermiste kinderen, terwijl Burgernet meer algemeen wordt ingezet. Hoewel het lastig is om effecten specifiek aan de input van burgers toe te schrijven, suggereren Cornelissen en Ferwerda (2010) dat het aantal criminelen dat op heterdaad wordt betrapt, is toegenomen door de inzet van Burgernet. Een aanvullend effect is dat burgers zich veiliger voelen door Burgernet, omdat hun gevoel van controle is toegenomen. Burgers zijn over het algemeen positief over hun deelname, zijn meer alert op verdachte situaties en hebben een positiever beeld van de politie (Cornelissen \& Ferwerda 2010).

Meijer e.a. (2011) onderzochten het verschil tussen Twitter en Burgernet en concludeerden dat Twitter van toegevoegde waarde is op SMS en telefoon. Het gebruik van Twitter had een positief effect op de betrokkenheid van burgers, maar omdat er minder aandacht aan Twitter wordt besteed dan aan SMS of de telefoon, beperkte het effect zich tot situaties die minder tijd-kritisch zijn. Twitter kan worden gezien als een technologie die ondersteunend is voor de zwakkere verbindingen in sociale netwerken (weak ties) en is daarmee aanvullend op technologieën die sterke verbindingen ondersteunen zoals SMS en telefoon. 


\subsubsection{Adviseren}

Bij de middelste categorie van de participatieladder hebben burgers wat meer invloed. Projecten die hier binnen vallen, gaan vaak over het vergroten van de leefbaarheid van een wijk. Bij projecten die zich op de openbare ruimte richten, kunnen twee subcategorieën worden onderscheiden: gedragscode projecten en wijkbudgetten (Van der Land e.a. 2014). Voor beide subcategorieën geldt dat het doel is om de sociale en fysieke leefbaarheid van de omgeving te bevorderen. Vooral de fysieke aspecten (schoon, heel en werkzaam) zijn van invloed op gevoelens van veiligheid (Blokland 2009). Een programma in Rotterdam (Opzoomeren, later 'Mensen maken de stad' genoemd) is exemplarisch voor beide subcategorieën, omdat zowel stadsetiquette als wijkbudgetten er onderdeel van uitmaken (Van der Land e.a. 2014). In dit programma kunnen burgers allerlei kleinschalige initiatieven bedenken om de leefbaarheid van hun woonomgeving te verbeteren, zoals betere verlichting, onderhoud aan voortuinen, maar ook het bevorderen van onderling contact. Basisidee is dat burgers elkaar beter leren kennen door samen activiteiten te ondernemen, zoals samen de groenvoorziening onderhouden of het organiseren van buurtfeesten. Daardoor neemt niet alleen de leefbaarheid en veiligheid toe, maar ook de sociale cohesie.

\subsubsection{Coproduceren/meebeslissen}

In de laatste categorie (coproduceren/meebeslissen) vallen projecten waarin burgers daadwerkelijk invloed hebben op het beleid en problemen gezamenlijk worden aangepakt. Er is een aantal projecten in deze categorie, waarbij 'Buurt Bestuurt' in Rotterdam waarschijnlijk wel de invloedrijkste is. 'Buurt Bestuurt' begon in 2009 met als belangrijkste doel om het publieke vertrouwen in de lokale overheid (waaronder de politie) te herstellen, om de problemen te identificeren die bewoners het belangrijkste vonden en om samen oplossingen te bedenken. Als zodanig is het gebaseerd op het Britse 'reassurance policing'-concept (Eysink Smeets, Moors, Jans \& Schram 2013).

Burgers die aan 'Buurt Bestuurt' deelnemen, hebben het gevoel dat zij een zinvolle bijdrage leveren aan het oplossen van problemen in de wijk, zij ervaren dat de samenwerking met professionals verbetert en hebben ook meer vertrouwen in professionals. Het aantal mensen dat actief bijdraagt aan Buurt Bestuurt is echter vrij klein en niet representatief voor de gehele wijk. Dit lage percentage actieve burgers is waarschijnlijk ook de reden dat er geen meetbare effecten op wijkniveau zijn gevonden (Eysink Smeets e.a. 2013).

\section{Conclusies}

Het doel van het huidige onderzoek was om de stand van zaken weer te geven van de effecten van GGPW, waarbij we een onderscheid hebben gemaakt tussen het organisatieniveau en de samenwerking met burgers. Vertrouwen kwam daarbij naar voren als een algemene noodzakelijke voorwaarde voor het succes van GGPW. Om het vertrouwen van burgers te bevorderen zijn met lokale zichtbaarheid en rechtvaardigheid van essentieel belang. 
Sociale media kunnen een goede bijdrage leveren aan zichtbaarheid en herkenbaarheid als aanvulling op de fysieke aanwezigheid van agenten in de wijk. Steeds meer wijkagenten gebruiken bijvoorbeeld Twitter en dit heeft een grote impact op de interactie tussen burgers en politie. Door de snelle en directe communicatie kunnen burgers steeds beter betrokken worden, maar aan de andere kant maakt toenemende zichtbaarheid ook kwetsbaarder, onder meer door de vage scheidslijn tussen privé en zakelijke informatie-uitwisseling.

Voor de organisatie betekent GGPW dat oplossingen optimaal moeten zijn afgestemd op de lokale context en op de behoeften van burgers en andere relevante belanghebbenden. Omdat deze aspecten variëren over wijken, hebben wijkagenten discretionaire ruimte nodig: zij moeten de ruimte hebben om, binnen algemene kaders, zelf beslissingen te nemen op basis van hun inschatting van de lokale situatie. Aan de andere kant moeten de positie en het functioneren van de wijkagent goed worden ingebed in de organisatiestructuur van de Nationale Politie. Voor maximale flexibiliteit is GGPW het best gebaat bij een relatief platte organisatiestructuur, die zo goed mogelijk een genetwerkte vorm van samenwerking faciliteert en ondersteunt.

De samenwerking tussen burgers en politie kan verschillende vormen aannemen. Op dit moment richten de meeste initiatieven zich nog op het informeren en consulteren van burgers, waarbij de daadwerkelijke invloed van burgers nog niet zo groot is. Aan de ene kant is dat begrijpelijk, omdat de politie, samen met de militaire organisatie, een geweldsmonopolie heeft en burgers slechts tot op zekere hoogte kunnen bijdragen. Aan de andere kant zijn er wellicht ook wel meer mogelijkheden (en is het ook wenselijk) om burgers meer te betrekken bij het oplossen van veiligheidsproblemen in hun eigen leefomgeving.

Het huidige onderzoek werd uitgevoerd in het kader van het Europese project INSPEC2T, dat als doel heeft om de volgende stap in de samenwerking tussen politie en burgers in verschillende landen te definiëren en te onderzoeken. De verwachting is dat burgers in de toekomst een steeds grotere rol zullen gaan spelen in alle domeinen van het politiewerk. Dit wordt gefaciliteerd door ICT-ontwikkelingen, waardoor, bijvoorbeeld, meldingen direct kunnen worden afgehandeld of burgers kunnen bijdragen aan opsporingsactiviteiten door het uploaden van video's. Daarbij zal uiteraard rekening moeten worden gehouden met zowel de juridische als culturele verschillen tussen landen.

$\mathrm{Al}$ met al is er een duidelijke maatschappelijke trend om meer gebruik te maken van het enorme potentieel aan capaciteit, kennis en kunde die burgers te bieden hebben. De vraag is daarom niet óf organisaties met deze trend mee moeten gaan, maar meer hoe structuur, cultuur en werkwijze zo goed mogelijk aangepast kunnen worden om de switch naar een meer genetwerkte manier van optreden te kunnen maken en het burgerpotentieel optimaal te benutten.

\section{Literatuur}

Akkermans, M. \& B. Vollaard (2015) Effect van het WhatsApp-project in Tilburg op het aantal woninginbraken - een evaluatie. Onderzoeksrapport Universiteit Tilburg. 
Arnstein, S.R. (1969) A ladder of citizen participation. Journal of the American Institute of Planners, 35(4), 216-224.

Bertot, J.C., P.T. Jaeger \& D. Hansen (2012) The impact of polices on government social media usage: Issues, challenges, and recommendations. Government Information Quarterly, 29(1), 30-40.

Beunders, H.J.G., M.D. Abraham, A.G. van Dijk \& A.J.E. van Hoek (2011) Politie en publiek. Een onderzoek naar de communicatievormen tussen burgers en blauw. Amsterdam: Reed Business.

Blokland, T. (2009) Oog voor elkaar: veiligheidsbeleving en sociale controle in de grote stad. Amsterdam: Amsterdam University Press.

Boin, R.A., E.J. van der Torre, P. 't Hart \& M.J. van der Meulen (2003) Blauwe bazen: het leiderschap van korpschefs. Politie \& Wetenschap.

Boverman, E., L. van Duijn, P. de Graaf \& J. Ritzema (2011) Politie, twitter en gezag. Warnsveld: Politie Nederland.

Bradford, B., J. Jackson \& M. Hough (2013) Police Legitimacy in Action: Lessons from Theory and Practice, in: M. Reisig \& R. Kane (eds.), The Oxford Handbook of Police and Policing. Oxford: Oxford University Press.

Braga, A.A., B.C. Welsh \& C. Schnell (2015) Can Policing Disorder Reduce Crime? A Systematic Review and Meta-analysis. Journal of Research in Crime and Delinquency, 52(4), 567-588.

Centraal Bureau voor de Statistiek (CBS) (2014) Integrale Veiligheidsmonitor 2014. Zoetermeer.

Cornelissen, A. \& H. Ferwerda (2010) Burgerparticipatie in de opsporing. Een onderzoek naar aard, werkwijzen en opbrengsten. Apeldoorn: Politie \& Wetenschap en Arnhem: Bureau Beke.

Eijk, G. van (2013) Veiliger door de buurtwacht? Over de veiligheidsbeleving van burgerparticipanten en het belang ervan voor lokaal veiligheidsbeleid. Tijdschrift voor Veiligheid, 12(3), 20-33.

Eysink Smeets, M., H. Moors, M. Jans \& K. Schram (2013) De bijzondere belofte van Buurt Bestuurt. Landelijke Expertisegroep Veiligheidspercepties.

Gill, C., D. Weisburd, C.W. Telep, Z. Vitter \& T. Bennett (2014) Community-oriented policing to reduce crime, disorder and fear and increase satisfaction and legitimacy among citizens: a systematic review. Journal of Experimental Criminology, 10(4), 399-428.

Gooren, W., P. van Os \& B. Rookhuijzen (2013) Gebiedsgebonden Politie als basis of sluitstuk?. Slotpublicatie van het programma Ontwikkeling Gebiedsgebonden Politie. Apeldoorn: Politieacademie.

Flight, S., A. van den Andel \& P. Hulshof (2006) Vertrouwen in de politie. Een verkennend onderzoek. Amsterdam: DSP-Groep.

Hough, M., J. Jackson, B. Bradford, A. Myhill \& P. Quinton (2010) Procedural justice, trust, and institutional legitimacy. Policing: A Journal of Policy and Practice, 203-210.

Land, M. van der, B. van Stokkom \& H. Boutellier (2014) Burgers in veiligheid: Een inventarisatie van burgerparticipatie op het domein van de sociale veiligheid. Den Haag: WODC.

Mazerolle, L., E. Antrobus, S. Bennett \& T.R. Tyler (2013) Shaping citizen perceptions of police legitimacy: A randomized field trial of procedural justice. Criminology, 51(1), 33-63.

Meijer, A.J., S.G. Grimmelikhuijsen, A. Bos \& D. Fictorie (2011) Burgernet via Twitter. Onderzoek naar de waarde van dit nieuwe medium. Rapport Universiteit Utrecht.

Meijer, A.J., S.G. Grimmelikhuijsen, D. Fictorie, M. Thaens \& P. Siep (2012) Politie \& sociale media: Van hype naar onderbouwde keuzen. Apeldoorn: Politie en Wetenschap. 
Roodenburg, D. \& H. Boutellier (2014) Weet wat je tweet: het gebruik van twitter door de wijkagent en het vertrouwen in de politie. Tijdschrift voor Veiligheid, 13(3), 35-53.

Terpstra, J. (2009) Community policing in practice: ambitions and realization. Policing, 4, 64-72.

Veltman, L. (2011) Twitterende wijkagenten en de beleving van burgers: Een onderzoek naar de effecten van een twitterende wijkagent (masterscriptie Public Administration, Enschede).

Vijver, K. van der \& O. Zoomer (2004) Evaluating community policing in the Netherlands. European journal of crime, criminal law and criminal justice, 12(3), 251-267.

Vries, A. de \& F. Smilda (2013) Social media: het nieuwe DNA. Doetinchem: Reed Business.

Vries de, M.S., C.D. van der Vijver (2002) Beelden van gezag bij de bevolking en bij de politie. Dordrecht: Stichting Maatschappij Veiligheid en Politie.

Weisburd, D. \& J.E. Eck (2004) What can police do to reduce crime, disorder, and fear?. The Annals of the American Academy of Political and Social Science, 593(1), 42-65. 